\title{
RESPUESTA DEL TRIGO AL RIEGO SUPLEMENTARIO EN LA REGIÓN CENTRAL DE SANTA FE
}

\author{
CAmussi, G. F. ${ }^{2} \&$ MARANO, R.P. ${ }^{1}$
}

\begin{abstract}
RESUMEN
El trigo (Triticum aestivum) es uno de los principales cultivos utilizados en las rotaciones agrícolas de la Región Central Santafesina. Su producción se ve limitada-especialmente- por déficit hídricos ocurridos en etapas críticas de definición del rendimiento. El objetivo del trabajo fue analizar la respuesta productiva del cultivo de trigo al riego suplementario, en condiciones de campo para la región central santafesina, con una variedad de ciclo largo. El método de riego empleado fue por inundación. Para estimar la evapotranspiración del cultivo (ETc) se aplicó balance hídrico. Se midió biomasa aérea (BA), índice de área foliar (IAF), índice de cosecha (IC), componentes del rendimiento (BG) y eficiencia de uso de agua (EUA). Las precipitaciones en el período agosto - octubre fueron menores a la histórica, lo que obligó a aplicar $160 \mathrm{~mm}$ en cuatro riegos. Hubo diferencias significativas de riego respecto a secano en consumo de agua, rendimientos, índice de cosecha y eficiencia de uso de agua.

Palabras clave: trigo, riego suplementario, eficiencia de uso de agua.
\end{abstract}

\section{SUMMARY}

\section{Response wheat to supplementary irrigation in the central region of Santa Fe.}

The wheat (Triticum aestivum) is one of the main crops used in the crops rotations of the Central Region of Santa Fe. Its production is especially limited by the water stress that happens in the critics stages for the yield determination. The objective of the work was to analyze the wheat productive response to additional irrigation in field conditions for the central region of Santa Fe. One variety, of long cycle, was used. The flow irrigation method was used. In order to estimate the crop evapotranspiration (ETc), the water balance was applied. The aerial biomass (BA), the foliar area index (IAF), the harvest index (IC), the yield components (BG), and efficiency of water use (EUA) were measured. The precipitations from August to October were smaller than the historical average, which forced to apply $160 \mathrm{~mm}$ in four irrigations. There were significant differences in water consumption, yields, harvest index, and efficiency of water use between the irrigated and the nonirrigated treatments.

Key words: wheat, supplementary irrigation, efficiency of water use.

1.- Profesor Adjunto Diagnóstico y Tecnología de Aguas de la Facultad de Ciencias Agrarias (UNL).

2.- Tesinista. Becario Cátedra de Diagnóstico y Tecnología de Aguas de la Facultad de Ciencias Agrarias (UNL) Kreder 2805. (3080) Esperanza. Tel. (03496)-426400. Email: germanfcamussi@yahoo.com.ar Manuscrito recibido el 18 de abril de 2008 y aceptado para su publicación el 10 de septiembre de 2008. 